Bangladesh J. Plant Taxon. 26(2): 169-177, 2019 (December)

(C) 2019 Bangladesh Association of Plant Taxonomists

\title{
MORPHOLOGICAL AND MOLECULAR IDENTIFICATION OF TEN PLANT PATHOGENIC FUNGI
}

\author{
Shamim Shamsi*, Mohammad Nurul Islam, Sarowar Hosen, Md. Al-Mamun, \\ Pranami Chowdhury, Mst. Selina Momtaz, Najmun Naher, Zuhra Yeasmin, \\ Sadia Sultana, Amina Khatun, Abu-Al-Islam and Md. Abul Bashar \\ Department of Botany, University of Dhaka, Dhaka 1000, Bangladesh
}

Keywords: Pathogenic fungi; Tissue planting method; ITS; PCR amplification; Sequence analysis.

\begin{abstract}
Ten pathogenic fungi of Deuteromycetes were isolated from seven angiospermic hosts such as pointed gourd, tomato, rice, wheat, maize, chickpea and jute. Morphological characterization and molecular analyses were performed for accurate identification of the isolated pathogenic fungi. The sequence results obtained using the ITS1 and ITS4 primers were compared with NCBI GenBank and BOL database using BLAST analysis. Fusarium chlamydosporum and Penicillium pinophilum are recorded first time from Bangladesh.
\end{abstract}

\section{Introduction}

Plants are extremely important for human and animals. Nowadays, diseases have becoming a worldwide problem and highly concerning factor. Plant diseases are caused by fungi, bacteria, viruses, etc. Fungi represent the major pathogenic micro-organisms that infect plants, causing huge economical loss. They constitute the largest number of plant pathogens and are responsible for a range of serious plant diseases. Fungal attack can be found on leaves, petioles, stems, pods and seeds of different plants and can cause severe damages in the field as well as in storage condition. Fungal diseases are also important constraints in grain legume productions (Njambere et al., 2010).

Cereal crops such as rice, wheat, maize; pulses such as chickpea; vegetable such as pointed gourd and fiber yielding plant such as jute suffer from various kinds of diseases. But correct identification up to species level of a plant pathogenic fungus is important for the development of effective disease control management, quarantine purposes and as a basis for making decisions to protect agricultural crops as well as other natural resources from fungal pathogens (Rossman and Palm-Hernandez, 2008). The identification, taxonomy and epidemiological analyses of fungal pathogens are increasingly dependent on modern molecular techniques, based on PCR amplification of conserved regions of the genome and sequencing of the resulting PCR products (Haynes et al., 1996; Sandhu et al., 1995; Makimura et al., 1994). Morphological identification of fungal pathogens is very common but information on molecular identification of fungal pathogens is rare in Bangladesh. So, the aim of the study was to investigate the morphological and molecular identification of pathogens associated with some selected cereal crops, pulses, vegetable as well as fiber yielding plant.

*Author for correspondence: <prof.shamsi@gmail.com>. 


\section{Materials and Methods}

Diseased plant samples such as rice, wheat, maize, chickpea (Bangladesh Agriculture Research Institute, Joydebpur, Gazipur), pointed gourd, tomato (Local markets, Dhaka) and jute (Bangladesh Jute Research Institute, Manikganj and Farmgate) were collected and used for the present investigation.

\section{Isolation and morphological identification of fungi}

Pathogens associated with selected samples were isolated with following "Tissue planting method" on PDA medium (CAB, 1968). Morphological structures of the pathogens were depicted with the help of Camera Lucida. Identities of the fungal isolates were determined following the standard literature (Thom and Raper, 1945; Raper and Thom, 1949; Gilman, 1967; Booth, 1971; Ellis, 1971,1976; Barnett and Hunter, 1972; Sutton, 1980; Ellis and Ellis, 1997).

\section{Molecular characterization of fungi}

Molecular identification was done following Islam and Mukherjee (2011) with some modification.

\section{DNA extraction}

Fungal mycelia were harvested by scraping the surface of 15 days old cultures with a sterile spatula from the test tube. One gm fungal mycelia were taken in $1.5 \mathrm{ml}$ eppendorf tube and placed in liquid nitrogen. The mycelium was immediately grinded with a homogenizer machine to get fine powder. $750 \mu \mathrm{l}$ of lysis buffers were added in each eppendorf tube and stir with a vortex to get homogenous mixture. The tubes were transferred to $65^{\circ} \mathrm{C}$ preheated water bath for 30 minutes. The samples were taken from the water bath and cooled down to room temperature. $700 \mu 1$ of chloroform: phenol (1:1) mixture was added and mixed gently. The samples were centrifuged at $12,000 \mathrm{rpm}$ for 5 minutes. The aqueous phase was transferred into fresh eppendrof tube and again mixed with $700 \mu \mathrm{l}$ of chloroform: phenol and centrifuged at $12,000 \mathrm{rpm}$ for 5 minutes. The aqueous phase was transferred to new eppendorf tubes and $70 \mu \mathrm{l}$ of $\mathrm{NaOAc}$ was added. Top off the eppendorf tube with $300 \mu \mathrm{l}$ isopropanol, gently inverted several times. DNA 'ropes' precipitate was seen here. The samples were centrifuged at $13,000 \mathrm{rpm}$ for 10 minutes to form DNA pellet. The supernatant was discarded and the pellet was washed with $70 \%$ ethanol. The pellets were air dried and dissolved in $100 \mu \mathrm{TE}$ buffer mixed with RNAse A (final concentration $10 \mathrm{mg} / \mathrm{ml}$ ). The samples were incubated for 30 minutes at $37^{\circ} \mathrm{C} .10 \mu \mathrm{NaOAc}$ was added to the tubes and top off the eppendorf tube with $750 \mu \mathrm{l}$ absolute ethanol and mixed gently. The samples were centrifuged at 13,000 rpm for 10 minutes. The supernatant was discarded completely, washed with $70 \%$ ethanol, air dried the pellet and dissolved in $100 \mu \mathrm{TE}$ buffer. The DNA was allowed to dissolve overnight at $4{ }^{\circ} \mathrm{C}$.

\section{PCR amplification}

Molecular identification of the isolates was performed using the internal transcribed spacer (ITS) regions. PCR amplification was conducted using the ITS1 (5'-TCCGTAGGTGAACCT GCGG-3') and ITS4 (5'-TCCTCCGCTTATTGATATGC-3') primers for the ITS regions. The PCR was carried out in $0.2 \mathrm{ml}$ PCR tube with 25 reaction volume containing $2.0 \mu 1$ Template DNA, $12.5 \mu \mathrm{l}$ Master mix, $1.0 \mu 1$ Forward Primer, 1.0 $\mu$ l Reverse Primer and $8.5 \mu$ l MilliQ $\mathrm{H}_{2} \mathrm{O}$. Reaction mixture was vortexed and centrifuged in a microcentrifuge. The PCR was initiated by an initial denaturation step at $94^{\circ} \mathrm{C}$ for 5 minutes following 30 cycles of 94,54 and $72^{\circ} \mathrm{C}$ each for 30 sec, with a final extension step of $5 \mathrm{~min}$ at $72^{\circ} \mathrm{C}$ and ended with $4^{\circ} \mathrm{C}$. PCR amplified products were stored in $-20^{\circ} \mathrm{C}$ freezer for analysis by resolving in $1 \%$ agarose gel. The gel was prepared using $1.0 \mathrm{~g}$ agarose powder containing ethidium bromide. Agarose gel electrophoresis was conducted in 
1× TAE buffer at 90 Volts and $300 \mathrm{~mA}$ for 40 minutes. One molecular weight marker $1 \mathrm{~kb}$ DNA ladder was electrophoresed alongside the ITS reactions. DNA bands were photographed by a Gel Documentation system (model: DI-HD, UK).

Sequencing analysis

PCR amplified products were purified by alcohol precipitation and sequenced through automated sequencer in Centre for Advanced Research in Sciences (CARS), University of Dhaka. To identify the genus and species of the isolates, the sequences were analyzed using the BLAST program (http://blast.ncbi.nlm.nih.gov) of the National Center for Biotechnology Information (NCBI, Bethesda, MD, USA) as well as BOL database.

\section{Results and Discussion}

Morphological identification

Ten pathogens viz., Aspergillus flavus (jute seed), Bipolaris oryzae (rice seed), Bipolaris sorokiniana (wheat leaves), Colletotrichum gloeosporioides (jute stem), Corynespora cassicola (tomato leaves), Fusarium sp. (maize seed), F. oxysporum (chickpea seed), F. solani (rice seed), Penicillium sp. and Trichoderma sp. (pointed gourd) were identified morphologically (Fig. 1).

\section{Key morphological features of the isolated fungi are given below:}

1. Aspergillus flavus Link, Mag. der Ges. Naturf. Freunde Berlin 3(1): 16 (1809). $\quad$ (Fig. 1A)

Colonies effuse, greenish. Mycelium well-developed, septate, profusely branched and hyaline. Cells multinucleate, conidiophores long. Sclerotium present. Conidia catenulate, dry, usually globose, smooth, green in color.

Specimen examined: Isolated from the seeds of accession No. A-3047 of Corchorus capsularis, Bangladesh Jute Research Institute, Dhaka, MA Mamun 4, 23 September 2014.

2. Bipolaris oryzae (Breda de Haan) Shoemaker, Canadian J. Bot. 37(5): 883(1959). (Fig. 1B)

Colonies greenish grey, reverse light grey, olivaceous with brownish tinge. Mycelium fluffy, aerial, cottony, septate. Conidiophores septate, solitary or in small groups; straight or flexous, sometimes geniculate; simple; pale to mid-brown; bearing conidia at the end and on sides. Conidia olivaceous brown, obclavate, fusiform, straight or curved, prominent hilum with basal scar, 5-9 septate, 39.56-101.89 × 11.96-16.10 $\mu \mathrm{m}$.

Specimen examined: Isolated from the seeds of Oryza sativa, Bangladesh Rice Research Institute, Joydebpur, Gazipur, P Chawdhury 192, 2 January 2015.

3. Bipolaris sorokiniana (Sacc.) Shoemaker, Canadian J. Bot. 37(5): 883(1959).

(Fig. 1C)

Colonies olivaceous brown to very dark becoming generally lighter towards the periphery, margin mostly smooth, sometimes wavy with easily recognizable dark band, large number of conidia usually present in the centre, sometimes entire colony covered by black shiny conidia making the colony black and shiny. Conidiophores brown, short, erect, in most cases single, bearing 1-6 conidia. Ellipsoid, dark brown, mostly straight or slightly curved, wall thick but less towards the ends, broadest in the middle, ends rounded, scar clear within the basal cell. Terminal portion of the end cells sub-hyaline, $68.0-98.6 \times 17.0-23.8 \mu, 6-9$ pseudoseptate.

Specimen examined: Isolated from seeds of Triticum aestivum, Bangladesh Agriculture Research Institute, Joydebpur, Gazipur, MS Momtaz 178, 27 December 2014. 
4. Colletotrichum gloeosporioides (Penz.) Sacc., Fung. Agrum. 2: 6 (1882).

(Fig. 1D)

Colonies effuse, greyish, reverse greyish black. Acervuli black, sub-epidermal but later the epidermis are ruptured and expose them. Hyphae septate, hyaline. Conidia hyaline, straight, obtuse at the apex, $11.2-25.2 \times 3.6-5.0 \mu \mathrm{m}$.

Specimen examined: Isolated from infected stem of Corchorus capsularis L., Bangladesh Jute Research Institute, Manikgonj, S Hosen 22, 25 August 2014.

5. Corynespora cassiicola (Berk. \& Curt.) Wei, Mycol. Pap. 34: 5 (1950).

(Fig. 1E)

Colonies effuse, greyish, thinly hairy. Mycelium mostly immersed; stroma absent. Conidiophores pale to mid brown, with up to 9 successive cylindrical proliferations. Conidia solitary or in chains of 2-6, very variable in shape. Obclavate to cylindrical, straight or curved, sub-hyaline to rather pale olivaceous brown or brown, smooth, with 4-20 pseudosepta, 48.6-131.4 $\times 12-23 \mu \mathrm{m}$.

Specimen examined: Isolated from Lycopersicon esculentum, Ananda Bazar, S Shamsi 2878, 6 February 2015.

6. Fusarium Link, Mag. der Ges. Naturf. Fre. Berlin 3(1): 10 (1809).

(Fig. 1F)

Colonies white in early stage and later changed to violet-purple. Monophialides and polyphialides with conidia in chain formation at the head. Macroconidia 1-3 septa, a slightly curved apical cell and a scarcely developed base cell. Microconidia oval form, with a flat base and no septa. Chlamydospores absent.

Specimen examined: Isolated from the seeds of Zea mays, BARI, Joydebpur, Gazipur, U Sadia 5, 7 August 2014.

7. Fusarium oxysporum Schltdl., Flora Berol., Pars secunda: Cryptogamia: 106 (1824)

(Fig. 1G)

Colonies whitish, cottony, with purple tinge at maturity. Mycelium hyaline. Microconidia borne on simple phialide arising laterally on hyphae. Microconidia hyaline, oval-ellipsoid cylindrical, 5-13 × 2.3-4 $\mu \mathrm{m}$. Macroconidia hyaline, straight to curved, 3-5 septate, 25-60 × 3-6 $\mu \mathrm{m}$.

Specimen examined: Isolated from the seeds of Oryza sativa, BARI, Joydebpur, Gazipur, P Chawdhury 165, 10 December 2014.

8. Fusarium solani (Mart.) Sacc., Michelia 2(7): 296 (1881).

(Fig. 1H)

Colonies whitish, cottony. Mycelium striate, sparse to dense floccose, at maturity brownish vinaceous pigmentation observed. Microconidia developed from lateral conidiophores. Phialides narrow slightly towards apex, 40-75 $\times 2-3.5 \mu \mathrm{m}$. Microconidia oval shaped, 0-1 septate, 8-17 $\times$ 2.5-4.5 $\mu \mathrm{m}$. Macroconidia hyaline, canoe shaped, 0-7 septate, 36-54 × 4.5-6 $\mu \mathrm{m}$.

Specimen examined: Isolated from the seeds of Oryza sativa, BARI, Joydebpur, Gazipur, P Chawdhury 192, 18 February 2014.

9. Penicillium Link, Mag. der Ges. Naturf. Freunde Berlin 3(1): 16 (1809).

(Fig. 1I)

Colonies typically exhibits certain striking characteristics. These include color and color changes, floccose, broadly spreading and wrinkled. Conidiophores arising from the mycelium singly or less often in synnemata, branched near the apex to form a brush like conidia bearing structures called phialides. Conidia pale green, 1-celled, mostly globose or ovoid, produced basipetally. 
Specimen examined: Isolated from Trichosanthes dioica, Ananda Bazar, Dhaka, AA Islam 08, 10 June 2014.

10. Trichoderma Pers., Neu. Mag. für die Botanik 1: 92 (1794).

(Fig. 1J)

Colonies green. Conidiophores hyaline, upright, much branched, not verticillate; phialides, single or in groups. Conidia hyaline, 1-celled, ovoid, borne in small terminal clusters; usually easily recognized by its rapid growth and green patches or cushions of conidia.

Specimen examined: Isolated from Trichosanthes dioica, Hatirpool Bazar, Dhaka, AA Islam 09, 18 August 2014.
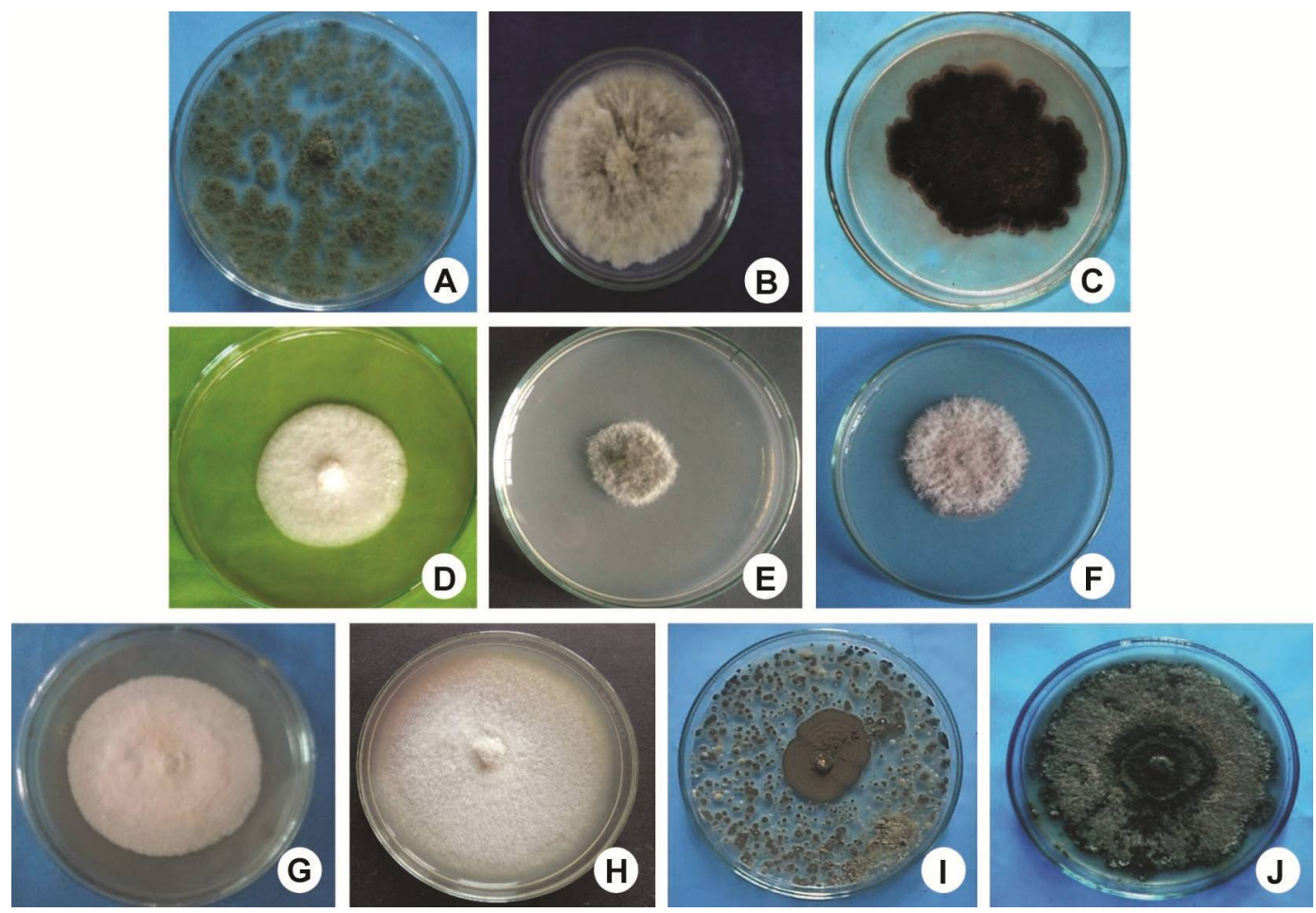

Fig. 1. Colonies of fungal isolates: A. Aspergillus flavus, B. Bipolaris oryzae, C. B. sorokiniana, D. Colletotrichum gloeosporioides, E. Corynespora cassiicola, F. Fusarium sp., G. Fusarium oxysporum, H. Fusarium solani, I. Penicillium sp. and J. Trichoderma sp.

\section{Molecular identification}

In the present investigation, it was difficult to identify some fungal species such as Fusarium, Penicillium, Trichoderma, etc. based on the morphological features. Therefore, molecular characterization of the fungal species was conducted for proper identification using sequence analysis of ITS region.

Ten isolates were identified by analyzing ITS regions sequences using the ITS1 and ITS4 as forward and reverse primers. In order to confirm at the genomic sequence level, PCR amplified bands ( $600 \mathrm{bp}$ ) from ten samples were subjected to automated sequencing followed by BLAST analysis (Fig. 2). 


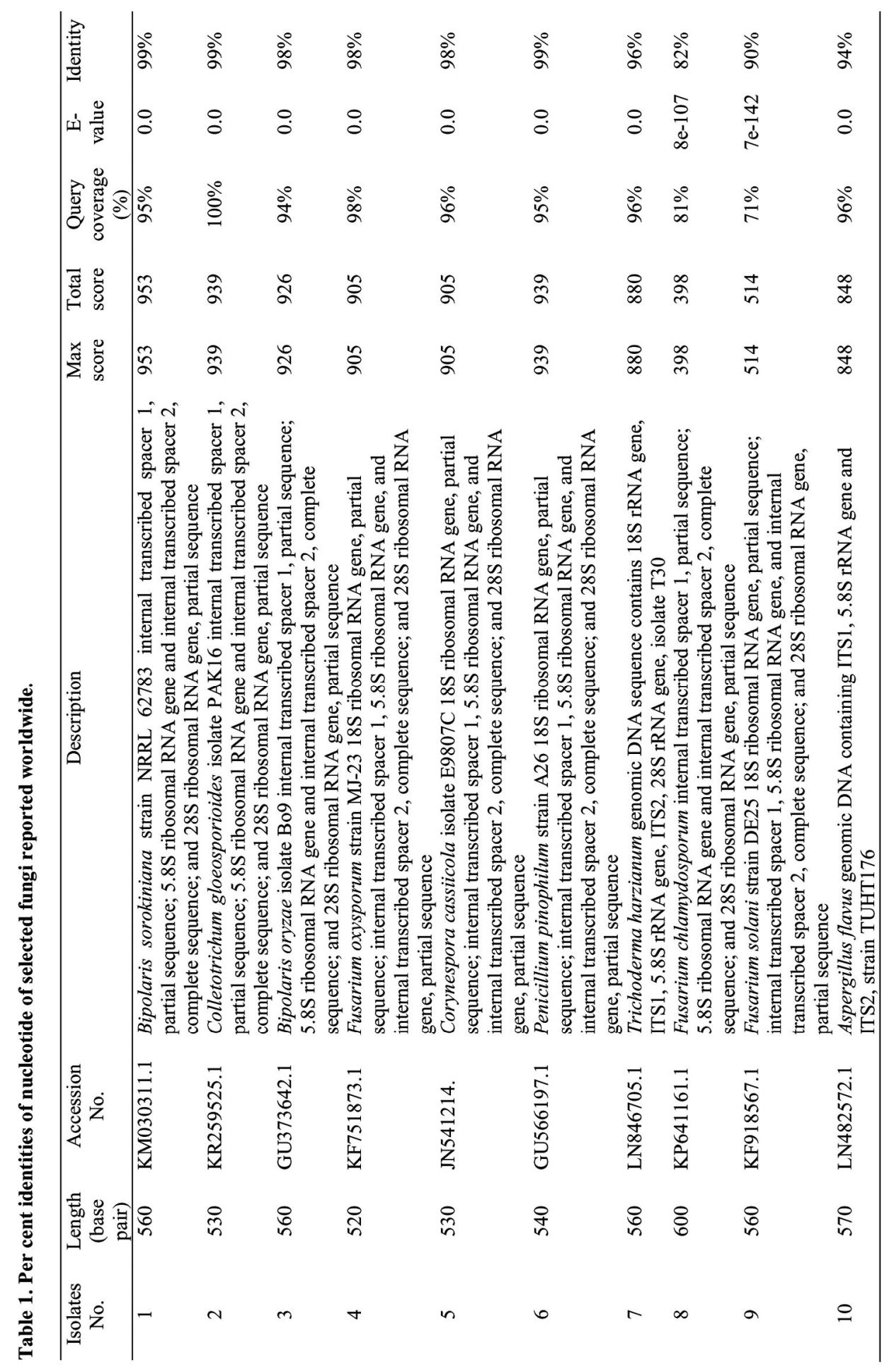




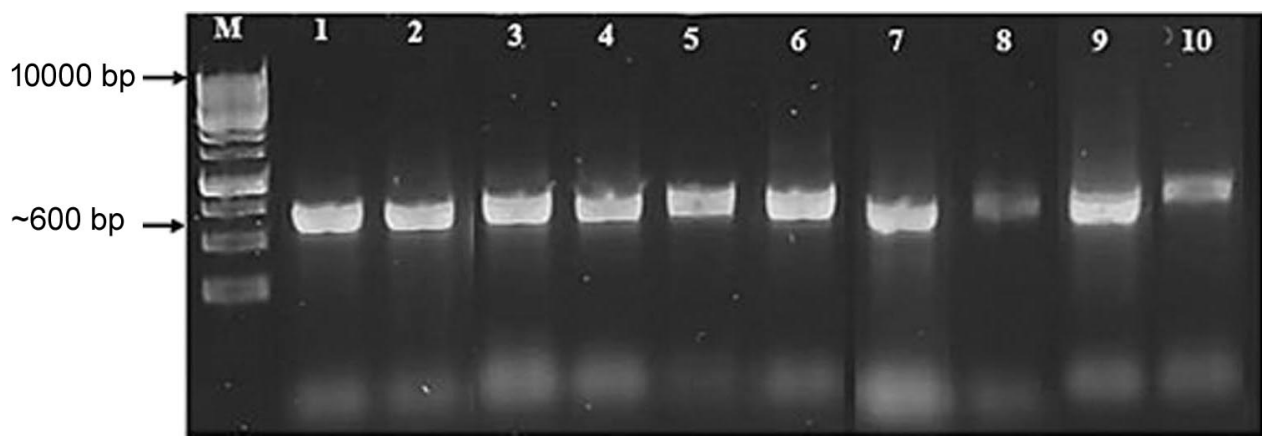

Fig. 2. Gel electrophoresis of the PCR product of 10 fungal isolates performed by ITS1(F) and ITS4 (R) primers and showing $\sim 600 \mathrm{bp}$ amplification.

Analysis of the nucleotide sequences of the amplified fragments allowed the identification of the isolates at the species level. ITS1 and ITS4 primers depicted the identities of the isolated fungi more than $90 \%$ sequence similarity except the isolate number 8 which showed $82 \%$ sequence similarity (Table 1).

ITS sequences of ten samples were analyzed through NCBI-BLAST program database search system. Results obtained from the BLAST database showed that $99 \%$ nucleotide identities with Bipolaris sorokiniana strain NRRL 62783, Colletotrichum gloeosporioides isolate PAK16 and Penicillium pinophilum strain A26; 98\% nucleotide identities with B. oryzae isolate Bo9, Corynespora cassicola isolate E9807C and Fusarium oxysporum strain MJ-23; 96\% nucleotide identities with Trichoderma harzianum genomic DNA sequence; 94\% nucleotide identities with Aspergillus flavus genomic DNA; 90\% nucleotide identities with Fusarium solani strain DE25 and $82 \%$ nucleotide identities with Fusarium chlamydosporum internal transcribed spacer 1.

Table 2. Comparison between morphological and molecular identification of ten fungal isolates.

\begin{tabular}{lll}
\hline $\begin{array}{l}\text { Isolates } \\
\text { No. }\end{array}$ & Morphological identification & Molecular identification \\
\hline 1 & Bipolaris sorokiniana & Bipolaris sorokiniana strain NRRL 62783 \\
2 & Colletotrichum gloeosporioides & Colletotrichum gloeosporioides isolate PAK16 \\
3 & Bipolaris oryzae & Bipolaris oryzae isolate Bo9 \\
4 & Fusarium oxysporum & Fusarium oxysporum strain MJ-23 \\
5 & Corynespora cassiicola & Corynespora cassiicola isolate E9807C \\
6 & Penicillium sp. & Penicillium pinophilum strain A26 \\
7 & Trichoderma sp. & Trichoderma harzianum genomic DNA \\
8 & Fusarium sp. & Fusarium chlamydosporum \\
9 & Fusarium solani & Fusarium solani strain DE25 \\
10 & Aspergillus flavus & Aspergillus flavus genomic DNA \\
\hline
\end{tabular}

Comparison between the morphological and molecular identification is presented in Table 2 . Out of ten fungal isolates, Fusarium sp., Penicillium sp. and Trichoderma sp. were not be able to identify morphologically up to species level. But with the help of molecular technique the above three fungi identified as species level such as Fusarium chlamydosporium, Penicillium pinophilum and Trichoderma harzianum. 
From the perusal of literature, it is revealed that Fusarium chlamydosporum and Penicillium pinophilum has not been reported in any relevant literature in Bangladesh (Shamsi et al., 2017, 2018; Siddiqui et al., 2007). Among the isolated fungi, Fusarium chlamydosporum and Penicillium pinophilum are new record for Bangladesh. Hence, Fusarium chlamydosporum and Penicillium pinophilum are reported here first time from Bangladesh.

The present investigation suggests that barcode based molecular technique is more accurate, rapid and reliable means of fungal identification. ITS-based molecular techniques may be a significant complement to traditional mycological detection by culture, which is becoming increasingly important in clinical mycology as well as plant pathology.

\section{References}

Barnett, H.L. and Hunter, B.B. 1972. Illustrated Genera of Imperfect Fungi. Burgess Pub. Co. U. S. A. pp. III +241 .

Booth, C. 1971. The Genus Fusarium. The Commonwealth Mycological Institute, Kew, Surrey, England. pp. 237.

CAB, (Commonwealth Agricultural Bureau) 1968. Plant Pathologist's Pocket Book. $1^{\text {st }}$ edn. The Commonwealth Mycological Institute, England. pp. 267.

Ellis, M.B. 1971. Dematiaceous Hyphomycetes. The Commonwealth Mycological Institute, England. pp. 608.

Ellis, M.B. 1976. More Dematiaceous Hyphomycetes. The Commonwealth Mycological Institute, England. pp. 608.

Ellis, M.B. and Ellis, J.P. 1997. Micro Fungi on Land Plants. An identification Handbook. The Commonwealth Mycological Institute, England. pp. 868.

Gilman, J.C. 1967. A Manual of Soil Fungi. Oxford and IBH Publishing Co., New Delhi, $2^{\text {nd }}$ edition (Revised). pp. $\mathrm{x}+450$.

Haynes, K., Westerneng, T. and Fell, J. 1996. Rapid detection and identification of pathogenic fungi by polymerase chain reaction amplification of large subunit ribosomal DNA. J. Med. Vet. Mycol. 33: 319-325.

Islam, M.N. and Mukherjee, S.K. 2011. Construction of MYMIV based gene silencing vector and its use. ISBN: 978-3-8443-8820-6. LAP-LAMBERT Academic Publishing GmbH \& Co KG. Dudweiler Landstr. 99, 66123 Saarbrücken, Germany.

Makimura, K., Murayama, S.Y. and Yamaguchi, H. 1994. Detection of a wide range of medically important fungi by polymerase chain reaction. J. Med. Microbiol. 40: 358-364.

Njambere, E.N., Attanayake, R.N. and Chen, W. 2010. Applications of molecular markers and DNA sequences in identifying fungal pathogens of cool season grain legumes. Gherbawy and Voigt (eds.), Molecular Identification of Fungi. Springer-Verlag Berlin Heidelberg. pp. 79-91.

Raper, K.B. and Thom, C. 1949. Manual of the Penicillia. Williams and Wilkins, Baltimore, MD, USA.

Rossman, A.Y. and Palm-Hernandez, M.E. 2008. Systematics of plant pathogenic fungi. Why it matters. Plant Dis. 92: 1377-1386.

Sandhu, G.S., Kline, B.C. and Stockman, L. 1995. Molecular probes for diagnosis of fungal infections. J. Clin. Microbiol. 33: 2913-2919.

Shamsi, S., Hosen, S. and Ahmed, A. 2018. Fungi associated with leaves of Sonneratia apetala Buch. Ham and Sonneratia caseolaris (L.) Engler from Rangabali coastal zone of Bangladesh. Dhaka Univ. J. Biol. Sci. 27(2): 155-162.

Shamsi, S., Hosen, S. and Begum, M. 2017. New record of Gonatophragmium mori (Sawada) Deighton on Ficus hispida L. from Bangladesh. Bangladesh J. Plant Taxon. 24(1): 125-127. 
Siddiqui, K.U., Islam, M.A., Ahmed, Z.U., Begum, Z.N.T., Hassan, M.A., Khondker, M., Rahman, M.M., Kabir, S.M.H., Ahmad, M., Ahmed, A.T.A., Rahman, A.K.A. and Haque, E.U. (Eds) 2007. Encyclopedia of Flora and Fauna of Bangladesh. Vol. 2. Cyanobacteria, Bacteria and Fungi. Asiatic Society of Bangladesh, Dhaka. pp. 415.

Sutton, B.C. 1980. The Coelomycetes. Fungi Imperfecti with Pycnidia, Acervuli and Stromata. The Commonwealth Mycological Institute, England. pp. 696.

Thom, C. and Raper, K.B. 1945. A Manual of the Aspergilli. Williams and Wilkins, Baltimore, MD, USA.

(Manuscript received on 10 February, 2019; revised on 11 December, 2019) 